\title{
Criminal Liability for the disseminator of Eigenrichting through Social Media : Law Number 11 of 2008 Concerning Electronic Information and Transactions
}

\author{
RM. Egidius Yuristha ${ }^{1 *}$, Eko Soponyono $^{1}$, Umi Rozah $^{1}$ \\ \{egidiusyuristha@ymail.com ${ }^{* 1} \underline{\text { eko_soponyono@live.undip.ac.id }}$, umi_rozah@live.undip.ac.id ${ }^{3}$ \}
}

Fakultas Hukum, Universitas Diponegoro, Jl. Prof. H. Soedarto, S.H., Semarang, Indonesia $50275^{1}$

\begin{abstract}
Following the development of the needs of the people, information technology plays an important role now and then. Information technology brings great benefits and interests to all countries around the world. The current technological developments is very impactful not only to the improvement of human welfare, progress, and civilization, but also as an effective tool against the law. One of acts against law is to spread eigenrichting through social media. The issues of this Legal Journal is to, first, find out about the provisions regarding the distribution of eigenrichting through social media based on the prevailing laws and regulations in Indonesia. Second, to describe and analyze accountability related to the distribution of Eigenrichting through social media, based on judges' consideration in Court Decision Number 217/Pid.Sus/2018/PN.Tng.
\end{abstract}

Keywords: Spreading Eigenrichting through Social Media, Eigenrichting, Criminal Responsibility

\section{Introduction}

Development in the field of information technology (with all its supporting aspects) is expected to have a positive impact on human life, which will ultimately lead to the creation of an increase in human well-being. [1] According to former Minister of Communication and Information Syamsul Muarif, technology has changed the pattern of human life in various fields, so that it has directly influenced the emergence of new legal actions in society. The forms of legal actions need to be adjusted by harmonizing several existing laws, replacing when they are no longer suitable, and forming new legal provisions. [2] Aside from having a positive impact, the internet also has a negative impact that clashes with the moral values that exist in Indonesia which, according to Didik J. Rachbini, causes the process of developing information technology to not yet reach a level of establishment. [3] Through the internet media several types of criminal offenses are increasingly easy to do such as, criminal acts of defamation, pornography, gambling, account break-ins, cyber network destruction (hacking), attacks through viruses (virus attacks) and so on.

In this legal paper, the writer will narrow down the discussion of some of the negative impacts of the internet through social media into a discussion of the spread of eigenrichting records through social media by discussing the vigilante case that occurred in Cikupa, Tangerang in 2017 which was viral and became the subject of discussion among Indonesian people. In short, the case started with a couple living in a boarding house, and was suspected 
by the citizens of committing immoral acts. Without any prior checking, residents conduct eigenrichting (vigilante) against the two lovers by carrying out mistreatment and coercion. Even the two lovers are paraded (exhibited) and exposed by residents including the local authority heads who participate in forcing the lovers to claimed that they had committed immoral acts in their contract. The incident was distributed by someone named Gusti Singgih Danuarta through Facebook. his action is then became a proof through a trial with Case Number 217/Pid.Sus/2018/PN.Tng, [4] and have been sentenced by a court which has the legal force of imprisonment for 10 months imprisonment for 10 months because it has been legally and convincingly proven to violate the provisions of Article 45 paragraph (1) jo. Article 27 paragraph (1) of Law Number 11 of 2008 concerning Information and Electronic Transactions. [5] Regulations regarding the dissemination of Electronic Information and/or Electronic Documents which have contents that violate decency are governed by Indonesian law, in Article 27 paragraph (1) of Law Number 11 of 2008 concerning Electronic Information and Transactions. The ITE Law has anticipated in such a way the adverse effects of the utilization of ITE technology advances. The ITE Law has determined which actions are included in criminal offenses in the field of ITE (cybercrime) and has determined the nature of evil and assaults on various legal interests in the form of specific criminal acts. [6]

In analyzing a court, decision above the author will discuss criminal liability for a criminal act. Criminal responsibility (criminal responsibility) is a mechanism to determine whether a defendant or suspect is responsible for a criminal act that occurs or not, which in this case is a decision with Case Number 217/Pid.Sus/2018/PN.Tng on behalf of the convict Gusti Singgih Danuarta.

Based on the background stated above, the following problems can be formulated:

1. How are the Criminal Provisions for the Perpetrators of Eigenrichting Spreading through Social Media Based on the Legislation in force in Indonesia?

2. What is the Responsibility of Perpetrators of Eigenrichting Distribution through Social Media Based on Judges' Considerations in Court Decision Number 217/Pid.Sus/2018/PN.Tng?

\section{Method}

Research is a basic tool in the development of science and technology. That is because the research aims to reveal the truth systematically, methodologically, and consistently. Methodological means something by a method or a certain, systematic is based on a system, whereas consistent means the absence of things that conflict with a particular framework. In the research process, analysis and construction of the data that has been collected and processed is carried out. [7]

The method of approach used in this legal research is normative juridical (legal research) which is a legal research conducted by examining library materials. [7] A juridical approach is an approach that refers to the applicable laws and regulations. [8] Normative Legal Research however, is a legal research method conducted by examining mere library materials or secondary data. [7] Regarding the term normative legal research, there is no uniformity among legal experts. Some of them mentioned in terms of normative legal research methods or library legal research methods; [7] doctrinal legal research methods; [9] normative legal research methods, [10] and; normative legal research methods or doctrinal legal research methods. [8] The normative method, is a method carried out by examining library materials or secondary 
data on the principles of law and case studies which in other words are often referred to as library law research. [8]

The choice of this method by the researcher is due to legal research is a process to find the rule of law, legal principles in order to answer the legal problems encountered. Therefore, the choice of method used in this study is normative legal research relating to the principles and rules of law that apply regarding criminal liability for the crime of spreading eigenrichting through social media and can solve problems objectively based on material related library materials. This research is intended to conduct a theoretical-normative study of the principles and norms/regulations regarding the specification of acts and the imposition of responsibility for the crime of spreading eigenrichting through social media as regulated in Law No. 11/2008 jo. Law Number 19 of 2016 Regarding Information and Electronic Transactions then links the discussion to Court Decision Number 217/Pid.Sus/2018/PN.Tng, so that a conclusion is found.

\section{Results and Discussion}

\subsection{Criminal Provisions for the Perpetrators of Eigenrichting Spreading through Social Media Based on Legislation in force in Indonesia}

Although the crime of spreading eigenrichting through social media has not been explicitly regulated in the Act, the practice of the provisions according to positive Indonesian law regarding the crime of spreading eigenrichting through social media are regulated in: [11]

Article 27 paragraph (1) jo. Article 45 paragraph (1) of Law Number 11 of 2008 Concerning Information and Electronic Transactions jo. Law Number 19 of 2016 concerning Amendments to Law Number 11 of 2008 concerning Information and Electronic Transactions; or

Article 27 paragraph (3) jo. Article 45 paragraph (3) of Law Number 11 of 2008 Concerning Information and Electronic Transactions jo. Law Number 19 of 2016 concerning Amendments to Law Number 11 of 2008 concerning Information and Electronic Transactions.

\footnotetext{
3.1.1 Criminal Formulation Distributing Electronic Information that Has Content that Violates Decency (Article 27 Paragraph (1) in conjunction with 45 Paragraph (1) of Law Number 11 of 2008 Regarding Electronic Information and Transactions)

Viewed from the technical/formulation point of view, the criminal act is a criminal offense in the Information and Electronic Transaction field because the object of the act is Electronic Information and/or Electronic Data. Meanwhile, viewed from the point of view of the nature of the prohibition (against the law), it can be grouped into criminal acts of decency. The main criminal offense is decency, while the means are by utilizing Information and Electronic technology. For this reason, the criminal acts of Article 27 Paragraph (1) jo. 45 Paragraph (1) may be referred to as lex specialis from the forms of criminal acts of decency in Chapter XIV Book II of the Criminal Code. The formulation of a criminal offense in Article 27 Paragraph (1) if specified consists of the following elements:

- Subjective Elements:

1. Error: on purpose

- Objective Elements.
} 
2. Against the Law: without rights

3. Actions:

- Distribute; and/or

- Casting: and/or

- Making it accessible:

4. Object:

- Electronic Information; and/or Electronic Documents that have content that violates decency.

\section{Error Element}

Deliberately there is no doubt that "on purpose" is part of the element of error, especially in the crime of dolus (dolus delict). In every criminal act of dolus, there is always an element of intent, although that element is often not explicitly mentioned in the formulation. According to Jan Remmelink, there are ways to do things, [12] because of the nature of the verb (active action) used in the formulation. it has been illustrated that to realize the action, it is always driven by a will. Unlike the case in the culpa crime, the element of kulpa always must be stated explicitly in the formulation. As is known by the Dutch WvS system, that all criminal offenses that do not include the element intentionally or kulpa, the criminal act is still required to have an intentional element, meaning that it is a dolus crime. [13] To prove the element of intent stated in the formulation of a crime in Article 27 Paragraph (1) jo. 45 Paragraph (1) of the Information and Electronic Transaction Law, there are a number of things that need attention: [6]

a. Information in Memorie van Toelichting

b. The state of the soul of the maker when performing an action

c. All circumstances are objective when an action is carried out

\section{Unlawful Element: Without Rights}

Objectively, the element lies in the contents of Electronic Information in the "state and nature" of the object. The maker has no right to carry out the act of transmitting, distributing and making accessible Electronic Information/Electronic Documents is located/because the contents of the information violate decency. it is either not attached to the state and position of the maker in relation to the use of electronic means or because the "email address" or "social media account" used to send Electronic Information does not belong to him. Opinion that states the nature of the law lies in the position of the maker is not right. [14] From a subjective point of view, the relationship of the "without rights" element is closer to the elements "on purpose". As explained previously, that elements are deliberately placed before the element "intentionally" in the structure of the formulation of criminal acts. based on the information of MvT, there is no doubt that intentionally addressed or included elements without rights. The maker knows that he has no right (prohibited, disgraceful) to transmit, distribute, make accessible Electronic Information and/or Documents which he knows violate decency. This means that when eigenricthing is spread through social media, if it contains acts that violate decency, then to protect the values of decency in society the act is subject to the provisions of Article 27 Paragraph (1) jo. 45 Paragraph (1) of the Information and Electronic Transaction Law, with the aim of upholding the values of decency living in the community.

\section{Elements of Deed: Distributing, Transmitting, Making Accessibility}

Distributing comes from the word "distribution" which means "distribution (distribution, delivery) to several people or to several places." [15] When connected with the object 
element, then the act of distributing is channeling or sharing or sending Electronic Information whose contents violate decency. While the root word "transmits" is "transmission" which means sending, transmitting, spreading messages and so on from one person to another. Transmitting means "sending or forwarding messages from one person to another". [15] If examined from the above understanding, the act of "distributing" and "transmitting" has a difference. Distributing is the act of spreading something from someone to many people. This means that the target to be addressed is to many people. While "transmitting" is the act of spreading something from one person to another, meaning that the target/goal is only individuals not to many people. In fact, the act of transmitting and distributing has the same nature. The point is, with both actions, some information is channeled to the destination - the recipient of the information. Therefore, to measure that both of these actions have been realized perfectly, is from the point of distribution of the intended information.

In contrast to the act of distributing and transmitting which is formulated in a more concrete form, the third act of "making it accessible" is abstractly formulated. Because of this nature, the meaning of distributing and transmitting is actually included in the act. All actions, whatever their form if they cause the distribution of Electronic Information/Electronic Documents to the recipient of information using computer equipment, those actions include actions that make them accessible. [6]

When viewed from the act of spreading eigenrichting through social media, it can be explained that this element is fulfilled if the creator after entering into social media then he shares (distributes) the recording/video of an eigenrichting crime that occurs in a place and the creator aims to Eigenrichting events can be seen by the general public or other users on social media such as Facebook, Twitter, Instagram, Email, and others.

\section{Object Element: Electronic Information and/or Electronic Documents that Have Content that Violates Decency}

The final element contained in the formulation of a criminal offense article 27 Paragraph (1)no. 45 Paragraph (1) of the Information and Electronic Transaction Law in the context of imposing this provision on the perpetrators of the distribution of eigenrichting on social media is "Electronic Information and/or Electronic Documents that Have Content that Violates Decency." As known that in the spread of eigenrichting through social media, objects that are disseminated are acts that usually occur in eigenrichting such as unpleasant acts, threats, persecution, decency, kidnapping, and even in some cases sexual violence. Actions like that are considered to have violated decency in society, meaning that by doing so it has damaged the norm of decency that has been maintained in the midst of the community so that people feel uneasy and disadvantaged. Furthermore, in this discussion, the author will explain the elements of the object, namely "Electronic Information and/or Electronic Documents that Have Content that Violates Decency." Please note the meaning of decency in the Information and Electronic Transaction Law is not clearly explained.

Furthermore, regarding the definition and limits of decency the author will explain based on expert opinion. The Electronic Information and Transaction Law does not provide a definition of "decency" to cause multiple interpretations and meaning bias. Bias meaning meant is the meaning of decency whether civilization or politeness as the meaning of the term morality in general or the meaning of morality is pornography which is identified with fornication and eroticism. [16] Whereas "Decency" according to the Big Indonesian Dictionary made by the Language Center of the Ministry of National Education comes from the root of the word "moral" which means "good language; civilized; polite "other than that also interpreted as" good customs; politeness; courtesy; civilization; decency." [15] 
While "pornography" according to the Big Indonesian Dictionary means "erotic depictions of behavior with paintings or writings to arouse lust" or in other meaning "reading material deliberately and solely designed to arouse lust in sex". [15] Thus, the meaning of decency and pornography is different. [16] Problems can arise from the element "which has a charge violating decency." It is not easy to set boundaries of understanding violating decency, especially the term "decency" in criminal acts of decency, because its understanding and scope is very broad and can vary according to the views and values prevailing in society. [17] In the Information and Electronic Transaction Law there is no information or instructions regarding this element. For this reason, normatively, we must look at the main source of criminal law, namely the Criminal Code, specifically regarding the phrase "decency". Regarding the forms of criminal acts of decency, as crimes are placed in Articles 281 to 303 bis Chapter XIV Book II. [6] While in the form of violations are placed in Article 532 to 544 Chapter VI Book III. So many types of crimes and violations of decency. In practice it can be a serious problem, because First, in these articles there is no information whatsoever about the meaning of decency (zeden). Second, there are so many criminal acts of decency both types of crimes and violations. [6] Because of the two conditions above, according to Adami Chazawi,[6] then in terms of looking for the element "which has a charge violating decency" can lead to three opinions. Very wide, wide, and narrow. These opinions include:[6]

1. Opinions are very broad. Judgments are based on the real state of being in society. Whether the form of an act has caused public unrest, as an indicator of the value of decency that has been violated. No need to adjust it (juncto) with the types of criminal acts of decency in the Criminal Code. This opinion is very broad.

2. Broad opinion. The assessment is based on the actual form of the act which must be adjusted to the act in the type and forms of the criminal act of decency, both in the form of crime in Chapter XIV Book II and violations in Chapter VI of Book III of the Criminal Code.

3. Opinion is narrow, it is enough to see Article 281 of the Criminal Code only.

\subsubsection{Criminal Formulation Distributing Electronic Information that Has} Contamination and/or Pollution Content (Article 27 Paragraph (3) in conjunction with 45 Paragraph (3) of Law Number 11 of 2008 Regarding Electronic Information and Transactions)

The element "which has a charge of insulting and/or defamation", the phrase "insulting and/or defamation" which is not the slightest explanation in the ITE Law, proves that the crime of ITE Article 27 paragraph (3) is a special part (lex specialis) of beleedging Chapter XVI Book II of the Criminal Code It is not possible for a judge to apply the ITE criminal act without considering the insulting law provisions in Chapter XVI Book II of the Criminal Code. [14]

The concept of contempt law consisting of 6 (six) kinds of criminal acts is fixed and cannot be denied anymore. One part of insults (beleediging) is pollution (smaad). It is as if the ITE Law distinguishes between pollution and insults, putting pollution in line with insults. As if, insults are a/one type of crime. It is as if defamation stands alone, free from insults. The phrases "and/or" of conjunctions "and" mean, that insults (as a type of crime) can occur simultaneously (cumulative) with defamation. However, it is not possible, because insults are not a type of crime. But rather a qualification of a group of criminal acts that contain the same nature (not the same elements). This means that it is only possible for one or several of these types of insults. Because of the inclusion of "insult" qualifications in the formulation, it implies that all types of insults in Chapter XVI Book II can occur 
simultaneously/simultaneously in one case with pollution. Because insults do consist of 6 kinds. Though events like that are not pollution.

In addition, including the phrase "good name" after the word pollution, also creates problems. The concept of contempt law, especially regarding pollution, the object of criminal acts is "honor" (eer) and "good name" (goede naam). [6] The conception of contempt law clearly distinguishes between honor and reputation. Has a different meaning, because it is distinguished. [14] Although separated by the word "or" ("of" between the words "honor" and "good name" in Article 310 Paragraph (1) of the Criminal Code, the two words have the same nature. [6] The same characteristic is that, as a result of the attack on the good name or honor (the two objects) it causes a feeling of decline or fall or pollution of one's dignity or dignity. He felt humiliated and ashamed, accompanied by anger, resentment, hurt, displeased - a feeling that torments people's hearts. [18] The difference, "honor" is a sense of self-worth or dignity - the dignity of a person who is based on the values (courtesy) of politeness in the life of the community. [18] For example, because someone is big/fat and his movements and thinking are slow, then someone is called "buffalo". According to courtesy manners are not good deeds. The act of humiliating others. According to the conception of the law of contempt, this act falls under mild humiliation (Article 315). While "good name" is a sense of self-esteem or dignity - based on a good view or assessment of the community regarding the condition and personal characteristics of a person in the association of life in society.[18] According to Satochid Kartanegara, a good name is an honor given to someone in relation to his position in society. [19]

Based on the explanation above, according to Adami Chazawi, in terms of applying the phrase "contempt and/or defamation" of Article 27 Paragraph (3) of the ITE Law in a case, it can lead to two interpretations, narrow and broad. [6]

1. Narrow interpretation.

Whereas Article 27 Paragraph (3) of the ITE Law only applies to defamation.

2. Broad interpretation

Regarding the term "contempt" must be interpreted as an insult in the meaning of the genus, for any act that attacks the honor and good name of the person. Acts that contain the nature of humiliation in the sense of the genus, are found in all forms of humiliation in Chapter XVI Book II of the Criminal Code. [20] By reason, that according to the WvS conception the term insult (beleediging) is the name (qualification) of groups of types of criminal acts based on the protection of the same legal interests. A legal interest regarding the upholding of the dignity of honor and the dignity of the good name of an individual. Aiming to achieve and maintain the peace and inner peace of people in the interaction of fellow members of society from the actions of others that create feelings of shame, discomfort, offense, polluted, humiliated, all of which give birth to feelings of displeasure, hatred, dissatisfaction, anger, a suffering that torments people's hearts. [6]

This broad interpretation is also in accordance with the wishes of the Dutch WvS formers as reflected in the Memorie van Toelichting (MvT) in relation to the insults (beleediging) of the Article to the President or Vice President (no longer valid based on the decision of the Constitutional Court); 1 December 6, 2006 No. : 013 -022/PUU-IV13-022/PUU-IV/2006). In this case MvT gives instructions that the word insult (beleediging) should be interpreted the same as the meaning (forms) of insult (beleediging) in Chapter XVI of the second book of the Criminal Code. [21] Based on logical interpretation (logicalche interpretatie), presumably the soul of this MyT statement can be used to give meaning/insult (or insulting) elements/phrases in the formulation of specific insulting criminal acts in many articles in the Criminal Code 
whose object is the honor and personal good name of the person (such as Article 142, 143) and those outside the Criminal Code (as in the ITE Law and the Broadcasting Law).

Based on this interpretation method, Article 27 Paragraph (3) jo. 45 Paragraph (1) of the ITE Law can be applied to all cases of insults in accordance with the types of insults in Chapter XVI Book II of the Criminal Code, namely: [6]

1. Pollution (Article 310);

2. Defamation (Article 311);

3. Minor insults (Article 315);

4. Defamation complaints (Article 317);

5. Lead to false allegations (Article 318);

6. Pollution of people who have died (Articles 320 and 321).

Seeing from the two interpretations above, it is the broad interpretation that is considered appropriate to interpret the word insult and defamation. In order to impose the provisions of Article 27 Paragraph (3) on acts of spreading eigenrichting through social media, interpretation is needed not only of defamation, but also other offensive offenses which may also be contained in Information and/or Electronic Documents distributed by the author on social media. As the author has explained above, insult is not a crime, but a qualification of several criminal acts that have an object that is the same, namely the attacking of one's dignity or reputation. An Electronic Information and/or Document that is distributed through the media about an eigenrichting event in practice cannot only contain the contents of defamation. But also in an act of spreading eigenrichting on social media it is also possible to contain defamation (Article 311), mild insults (Article 315), lead to false allegations (Article 318). Therefore, a broad interpretation method is needed to understand the meaning of the phrase "contempt" or "good name" in order to impose the provisions of Article 27 Paragraph (3) of the ITE Law on acts of spreading eigenrichting through social media.

From each element contained in Article 27 Paragraph (3) jo. 45 Paragraph (3) This ITE Law has been proven that every element has been fulfilled if it is associated with the act of spreading eigenrichting through social media. Law enforcers in handling a case of the spread of eigenrichting through social media that occur in the community should have other options besides Article 27 Paragraph (1) of the ITE Law concerning the dissemination of decency content and may apply the provisions of Article 27 Paragraph (3) to these acts. This is because in the ITE Law it does not explicitly mention criminal provisions or material actions in the distribution of eigenrichting through social media. However, if we see from the object to be protected from these articles, namely the upholding of decency and the maintenance of a good name/honor, then we can understand that an act of spreading eigenrichting events on social media in the form of video or picture recording is sure to damage the order of norms morality in the community. In addition, this act has also attacked the honor/good name of someone who must be guarded regardless of the person's background, because basically everyone has selfrespect in the field of honor and good name, regardless of how bad a person's temperament or the lowest social position (including one's economic position, it is certain that the person still feels a sense of dignity/dignity regarding respect and good name. [6]

\subsection{Criminal Liability of Perpetrators of Eigenrichting Spreading Through Social Media Based on Judge's Consideration in Court Decision Number 217/Pid.Sus/2018/PN.Tng}


As the author explained above, to determine whether a person should be criminally responsible for his actions, according to Sudarto there are at least 3 elements that must be met, including: the ability to be responsible, the inner connection between the creator and his actions whether in the form of deliberate or negligence, and no excuse forgiveness. For this reason, the author will describe one by one the three elements of criminal liability above by referring to Sudarto's opinion of the judges' consideration in Court Decision Number 217/Pid.Sus/2018/PN.Tng.

\subsubsection{Responsible Ability}

According to Sudarto, the Criminal Code does not contain when someone is capable of being responsible. [22] However, the Criminal Code contains provisions that point in that direction, is in Book I Chapter II Article 44 which reads: "Whoever commits an act that cannot be accounted for him, because his soul is disabled in the growth or disturbed his soul due to illness, not convicted". There is contained a reason contained in the maker, which is the reason so that the deeds committed cannot be insured to him. The reason in the form of the personal condition of the creator who is biological, is "his soul is defective in growth or disturbed due to disease". In that situation the maker does not have freedom of will and cannot determine his will towards his actions. So this situation can be a reason for the creator not to be responsible for his actions.

According to Roni Wiyanto, Article 44 Paragraph (1) of the Indonesian Criminal Code in essence shows the conditions when a person is deemed not to have the ability to be responsible, which must meet the following conditions: [23]

1. The soul is flawed in growth. In this case what is meant is imperfect reason (thought) so that the nature and actions are childish, such as: idiot, blind, deaf, imbicil (dumb), or mute from birth. People who are classified as this kind are called abnormal.

2. The soul is disturbed due to illness. In this case what is meant is people who experience psychiatric illnesses, such as: psychosis, neurological disease (epilepsy), hysterics, and other mental illnesses. Mental disorders in this group are called pathological diseases.

If related to the judge's consideration or the facts of the trial in Decision Number 217/Pid.Sus/2018/PN.Tng, Convicted Gusti Singgih Danuarta is a person who is capable of being responsible for his actions in spreading eigenrichting through Facebook social media. In the facts of the trial there were no indications or signs that Gusti Singgih Danuarta experienced a "soul with disabilities in growth" or "his soul was disrupted by illness" as explained by Sudarto and Roni Wiyanto. The reason is that it is not possible for someone who has a disability or a disturbed soul to do the act of accessing social media in this case Facebook then sees the video and downloads it using UC Browser and re-uploads the video by adding a description to the video "Mangkanya Kalo Ngewe Modal", "Lok Tangerang Tigaraksa Kaloga Salah." This means that here there is a series of actions in using Electronics that can only be understood by normal people. The convict Gusti Singgih Danurta had full awareness and realized his actions with a normal state of mind and with this awareness he wanted to spread eigenrichting records of a couple who were accused of being perverted and made many people on social media see it.

Therefore, in its consideration, the judge determines:

"Considering whereas the Defendant, Gusti Singgih Danuarta bin (deceased) Sunaryo, at the hearing has provided information which in essence is as follows: 
That the Defendant is physically and mentally healthy and the Defendant has provided information in the Police Investigator and confirmed all of the Defendant's statements to the Investigation Agency."

\subsubsection{The Inner Relationship Between the Creator and His Acts (Deliberate or Negligence)}

The actions of the convicted Gusti Singgih Danuarta were not negligence or culpa. First, it should be noted that in the claim, the article used is an article which contains intentional elements, namely the element "intentionally", here it is clear that what the convict did was not an negligence or culpa. Because in the formulation of offense negligence is always mentioned with the term "because of his negligence" in the element of offense. For example, Article 188 of the Indonesian Criminal Code "because of negligence has caused eruption, fire, etc.," Article 359 "because negligence has caused the death of a person", Article 360 "because negligence causes a person to be seriously injured", etc. [22] Second, to find out someone is neglecting the experts think at least there are elements that must be fulfilled in his actions. Here the author uses Simons' opinion, [22] that is, to prove someone's negligence there are two elements, among others: (1) the absence of caution, (2) the expected consequences. Based on the facts of the trial that the author has explained before, the convict Gusti Singgih Danuarta did not fulfill the two elements of negligence. Because what convicted Gusti Singgih Danuarta is doing here is not something done in the absence of caution. It is very clear that the convicted Gusti Singgih Danuarta based on the evidence and legal facts of the trial carried out the act of spreading eigenrichting on social media Facebook against a pair of lovers accused of indecent acts with the intent and purpose that to be accessible and known to many people, where the content distributed violates decency. in the community. This means that with full awareness of the convict Gusti Singgih Danuarta realizing that he can determine his actions.

Furthermore, from the three features of intentionality according to Sudarto, the actions of the convicted Gusti Singgih Danuarta based on the judge's judgment in the court's decision were intentional as intentions (opzet als oogmerk). A person can be said to be opzet als oogmerk if he intentionally performs an action with the intent and purpose to cause a result of his actions. [23] Here it gives an understanding that if he does not want a result if a certain action is carried out, then he will not do the action. Thus, deliberate as an intention can be reviewed from two things, as follows: [23]

1) Formal Criminal Acts, i.e. if a person intentionally commits an act, and the act that is carried out is indeed the will of that person.

2) Material Crimes, i.e. if a person intentionally commits an act to cause a result of his actions. The resulting effect is the goal to be achieved by the perpetrator by carrying out an act.

Here, the convicted Gusti Singgih Danuarta's coverage covers both types of criminal acts. First, the convicted Gusti Singgih Danuarta had the intention, namely by deliberately downloading using the UC Browser video/recording eigenrichting of a couple for allegedly committing a pervert, to then disseminate information or electronic documents in the form of 2 videos by re-uploading the 2 videos through his personal account called "Gusti Singgih Danuarta" on Facebook using his cellphone. This means that the convicted Gusti Singgih Danuarta has committed an act which is a formal criminal offense. Second, the convict Gusti Singgih Danuarta has a purpose or purpose. For their acts of distribution by re-uploading electronic information or electronic documents containing the recordings of a pair of lovers paraded, tortured, and stripped by a group of people, here the purpose and purpose of the 
Convicted Gusti Singgih Danuarta is so that the video/recording can be accessed and known by many people. This was proven in distributing the recording Through Social Media Facebook, Convicted Gusti Singgih Danuarta Also Added The Video With The Title "Mangkanya Kalo Ngewe Modal", "Lok Tangerang Tigaraksa Kaloga Salah." This means that the convicted Gusti Singgih Danuarta has the intention that many people can access and view the videos he uploaded/share on his Facebook account.

\subsubsection{There is no Reason to Forgive}

Article 44 of the Criminal Code contains a provision that cannot be convicted of someone who commits an act that cannot be accounted for because his mind/soul is imperfect or disturbed due to illness. [22] As you know, M.v.T states that it cannot be accounted for because of the cause that lies within the maker. The convict Gusti Singgih Danuarta is a person with a normal mental state. Because based on legal facts during the trial court did not find a mental defect or lack in the soul growth of Gusti Singgih Danuarta. In the judge's judgment it was stated "that the Defendant Gusti Singgih Danuarta at the hearing had provided information in principle that the Defendant was physically and mentally healthy and the Defendant had provided information at the Police Investigator and confirmed all of the Defendant's statements to the Investigation Investigation Report". This means that the provisions of Article 44 of the Criminal Code do not apply to convict Gusti Singgih Danuarta.

Furthermore, in forgiving reasons, it is also regulated in Article 51 Paragraph (2), which is to carry out illegal orders. An illegitimate office order abolishes a person can be criminalized. This person's actions remain unlawful, but the author is not convicted, if he meets the following conditions:[22]

1. If he thinks in good faith (honest heart) that the command is valid.

2. The order is located within the authority of the person being governed.

When talking about job orders, the offender must be someone who has a certain job or profession in which there is separation and classification of positions. Based on the identity contained in the decision Gusti Singgih Danuarta is a person who works as a private employee. This means that Gusti Singgih Danuarta is someone who has a job and allows for the classification of certain positions within his work environment. However, even though his work allows for a certain position, it seems impossible if in his work environment he gets a position order to distribute on social media Facebook 2 video/eigenrichting record of a pair of lovers who are paraded, stripped, and beaten with the aim of the recording can be accessed and seen a lot Facebook user people. Likewise, in the legal facts of the trial it was not found that the Defendant's actions were illegal orders, but the Defendant's actions were purely intentional Gusti Singgih Danuarta with the intent and purpose in accordance with his conviction and consciousness.

The next reason for forgiveness is the forced defense which exceeds the limit (Nodweer Excess) in Article 49 Paragraph (2) of the Criminal Code. For the existence of this emergency defense, limit capability there must be the following conditions: [22]

1. exceeding the required defenses

2. the defense is carried out as a direct result of a great soul shake

3. The great mental shock is caused by an attack, in other words, between the mental shock and the attack there must be a causal relationship.

Then by looking at the facts of the trial in the decision there is not a single condition that fulfills the actions of the convicted Gusti Singgih Danuarta as a forced defense that exceeds 
the limit, because Gusti Singgih Danuarta committed his actions intentionally and not in an attempt to defend the attack that happened to him so it is not there may be a great mental shock in Gusti Singgih Danuarta. This also applies to reasons for forgiving overmacht or forced power contained in Article 48 of the Criminal Code. This provision states that a person who commits an act that is forced by force is not convicted. [22] According to M.v.T. force is described as "every force, every unbearable force or pressure." Whereas according to the facts of the trial law there is not a single coercion/pressure/force that forced Gusti Singgih Danuarta to carry out the act of spreading eigenrichting through social media which contained eigenrichting acts on a pair of lovers accused of lewd acts, then paraded, tortured, and stripped naked around the village. However, with his own awareness Gusti Singgih Danuarta carried out his actions and with the intent/purpose that the recording/video can be seen by many people.

Judging from the author's explanation above, Gusti Singgih Danuarta is not someone who should be given a reason to forgive himself so that he cannot be accounted for. Therefore, looking at the judge's judgment in Court Decision Number 217/Pid.Sus/2018/PN.Tng, the court did not find any excuse or justification reasons, or other criminal eradication reasons as specified in the applicable laws and regulations. The following considerations:

"Considering, that during the trial proceedings, the Court did not find any reasons that were used as excuses for forgiveness, justification and other reasons for criminal offenses as determined in applicable laws and regulations."

It is described by the author of each criminal liability requirement according to Sudarto, with regard to the consideration of judges in Court Decision Number 217/Pid.Sus/2018/PN.Tng. From the description of the criminal liability, the convicted Gusti Singgih Danuarta fulfills all elements of criminal liability. So Gusti Singgih Danuarta cannot be said to be someone who cannot be accounted for, but he must be held accountable for his actions in spreading videos/eigenrichting recordings of a pair of lovers through the social media of Facebook which is known in the video that there are violent content, nudity, narratives that violate decency with the intent/purpose so that many people can be accessed and seen for their actions. The convicted Gusti Singgih Danuarta was sentenced to a 10-month prison sentence and a fine of Rp 10,000,000.00 (ten million rupiahs) in one month's jail.

\section{Conclusion}

Based on the description that has been described in the discussion above, a conclusion can be drawn as follows:

1. The Information and Electronic Transaction Law does not explicitly regulate the act of spreading eigenrichting through social media, and instead, it enforcers to have the option to impose such acts based on the provisions of Article 27 Paragraph (1) jo. 45 Paragraph (1) or Article 27 Paragraph (3) jo. 45 Paragraph (3). This means that even it is not explicitly regulated in the Electronic Information and Transaction Law regarding the spread of eigenrichting through social media, there is something that the Lawmakers want to protect by upholding the values of decency in society and preserving one's honor or good name. 
2. To be able to determine someone is capable of being accounted for a criminal act, there is a mechanism called criminal liability. Based on the judge's decision Number 217/Pid.Sus/2018/PN.Tng, the judge has assessed that the eigenrichting spreader through social media of Gusti Singgih Danuarta is considering the elements of accountability as stated by Soedarto. As a result, the conviction of Gusti Singgih Danuarta was sentenced to a 10-month prison sentence and a fined with Rp $10,000,000.00$ (ten million rupiahs) for one month's prison sentence. 


\section{References}

[1] E. Mansur, D. M. A., and Gultom, Cyber Law: Aspek Hukum Teknologi Informasi. Bandung: Refika Aditama, 2009.

[2] S. Muarif, "Menunggu Lahirnya Cyber Law," 26 Dec 2004. [Online]. Available: https://www.cybernews.cbn.net.id. [Accessed: 20-Mar-2019].

[3] D. J. Rachbini, Mitos dan Implikasi Globaliosasi: Catatan Untuk Bidang Ekonomi dan Keuangan. Kata Pengantar dalam Edisi Indonesia, Paul Hirst dan Grahame Thompson, "Globalization and Question”, Globalisasi Adalah Mitos. Jakarta: Yayasan Pustaka Obor Indonesia, 2001.

[4] Tangerang District Court, Decision No. 217/Pid.Sus/2018/PN.Tng. in 2017. .

[5] Law Number 11 of 2008 Regarding Information and Electronic Transactions. .

[6] A. Chazawi, A., and Ferdian, Tindak Pidana Informasi \& Transaksi Elektronik. Malang: Bayumedia Publishing, 2011.

[7] S. Soekanto, S., and Mamuji, Penelitian Hukum Normatif Suatu Tinjauan Singkat. Jakarta: Raja Grafindo Persada.

[8] R. H. Soemitro, Metodologi Penelitian Hukum dan Jurimetri. Jakarta: Ghalia Indonesia, 1988.

[9] S. Wignjosoebroto, Hukum, Paradigma Metode dan Dinamika Masalahnya, (Eds Ifdhal Kasim et.al. Jakarta: Elsam dan Huma, 2002.

[10] H. Sunaryati, Penelitian Hukum di Indonesia pada akhir Abad ke-20. Bandung: Alumni, 1994.

[11] Law Number 19 of 2016 concerning Amendments to Act Number 11 of 2008 concerning Information and Electronic Transactions. .

[12] J. Remmelink, Hukum Pidana: Komentar atas Pasal-pasal Terpenting dari KUHP Belanda dan Padanannya dalam KUHP Indonesia. Jakarta: Gramedia Pustaka Utama, 2003.

[13] Moeljatno, Azas-Azas Hukum Pidana. Jakarta: Bina Aksara, 1983.

[14] A. Chazawi, "Sifat Melawan Hukum Penghinaan dalam UU ITE Bikin Polemik Lagi," 28 Jan $2010 . \quad$ [Online]. Available: https://www.kompasiana.com/adamicazawi/54ff695ba33311894c510155/sifatmelawan-hukum-penghinaan-dalam-uu-ite-bikin-polemik-lagi. [Accessed: 20-Mar2019].

[15] Departemen Pendidikan dan Kebudayaan Republik Indonesia, Kamus Besar Bahasa Indonesia Pusat Bahasa, 4th Ed. Jakarta: Gramedia Pustaka Utama, 2008.

[16] B. Suhariyanto, Tindak Pidana Teknologi Informasi (Cybercrime): Urgensi Pengaturan dan Celah Hukumnya. Jakarta: Raja Grafindo Persada, 2013.

[17] B. N. Arief, Tindak Pidana Mayantara. Jakarta: Raja Grafindo Persada, 2006.

[18] A. Chazawi, Hukum Pidana Positif Penghinaan (Tindak Pidana Menyerang 
Kepentingan Hukum Mengenai Martabat Kehormatan dan Martabat Nama Baik Orang Bersifat Pribadi Maupun Komunal). Surabaya: Putra Media Nusantara, 2009.

[19] S. Kartanegara, Hukum Pidana II Delik-Delik Tertentu. Jakarta: Rineka Cipta, 1991.

[20] J. Satrio, Gugat perdata atas dasar penghinaan sebagai tindakan melawan hukum. Bandung: Citra Aditya Bakti, 2005.

[21] P. A. F. Lamintang, Dasar-dasar Hukum Pidana Indonesia. Jakarta: Citra Aditya Bakri, 1997.

[22] Sudarto, Hukum Pidana I. Semarang: Yayasan Sudarto, 1990.

[23] R. Wiyanto, Asas-Asas Hukum Pidana. Bandung: Mandar Maju, 2012. 